\title{
THE RULES OF ACTUSREAUS AND MENS REA IN INTERNATIONAL CRIMINAL LAW OUGHT TO THE SUPPORT VICTIMS OF HUMAN RIGHTS VIOLATIONS THROUGH LIABILITY OF COMBATANTS
}

\author{
Ivan Mugabi*
}

\begin{abstract}
The normative principles of criminal law were in some cases founded upon concepts of individual criminal responsibility for a person's unlawful conduct. However under international criminal law the challenges of individual criminal responsibility may tend to arise from the effects of the hierarchal based-leadership structures that are used in the military. The hierarchal based structures are operationalised through a line of command which enhances maximum obedience to the instructions issued by military leaders. Disciplinary actions could be used under the military codes of practice to encourage compliance with the line of command. Possibly the line of command might be contributing to some cases of human rights violations. The problems that the line of command might creat to individual criminal responsibility are dealt with under this article. Cases where the members of armed forces are instructed by their superiors to act upon the instructions that are inconsistent with norms of human right protection are taken into account by this paper. The paper considers that in other cases those instructions have turned out as; misleading, misguiding or founded upon misconceived facts that may result into war crimes or crimes against humanity. This article examines how the principles of private criminal law have contributed in responding to the challenges of international criminal law. The article also examines if these developments have reshaped the ways of pursuing post conflict justice for the violations of human rights.
\end{abstract}

INTRODUCTION

I. PRinciples of Normative CRiminal LAW in PRIVATE CRiminal LAW500 A. 'ActusReus' in Private Criminal Lawunder Common Law

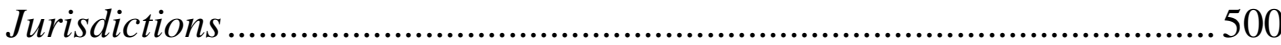

B. 'ActusReus' under International Criminal Law ........................501

C. 'Mens Rea' in Private Criminal Law under Common Law...... 501

D. Contrasting Civil Law Systems with the Common Law Criminal

Law 502

II. The HieRARCHY STRUCTURES OF LEADERSHIP IN Military LAWS AND

INTERNATIONAL CRIMINAL LAW .... 502

*Ivan Mugabi, Ph.D. on Disabilities human rights and law of Armed conflict, Cardiff University. Research fields: Human Rights, Disability and Equality Laws, Laws of Armed Conflict, International Criminal Law, Public International Law. 
III. CAUSATION OF THE HUMAN RIGHTS ViOLATIONS...................................503

IV. INCHOATE AND CRIMES OF COLLECTIVE PARTICIPATION........................503

V. INTERNATIONAL CRIMINAL LAW AND ITS SUBJECTS CONTRASTED WITH

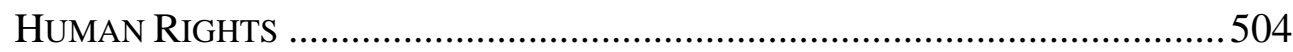

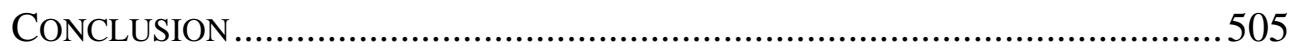

\section{INTRODUCTION}

The paper examines how the influence of hierarchal structures poses challenges to a normative view that mankind is primarily responsible for; choosing between criminal behaviour and linking such behaviour to challenges of protecting fundamental human rights. This paper shall explore how and why the chain of command the military codes of practice create distinctively unique circumstances to the traditional rulesof private criminal law meant for regulating principles of 'actusreus' and 'means rea' if perceived under lenses of international criminal law.

The first part of this paper gives a brief overview of how the main systems of private criminal law conceive the elements of 'actusreus' and 'means rea'. Conversely the conceptualisation of those elements in private criminal law is contrasted with that of international criminal law. The second part of this paper shall explain the rationale of having hierarchal structures of military leadership in relation to actions and instructions made in armed conflicts. the second part proceeds to examine the implications such instructions might have on the liberty of the subordinates combatants in terms of their 'actusreus' and 'means rea' before engaging in gross violations of human rights or even war crimes. Third part explains how the subordinate and line of command can be linked to situations of human rights violations in situation of armed conflicts. Part four relates to how the concept of inchoate offences has been applied to extent accountability to those in charge, who might notdirectly act but whose instructions or orders are aimed at making others act in a manner that is intended to cause gross violations of human rights. In the fifth section the paper examines the uniqueness in the nature of international criminal law in relation to international human rights law using their horizontal and vertical modes of enforcement. 


\section{Principles of Normative Criminal LaW in Private Criminal LaW}

\section{A. 'Actus Reus' in Criminal Law under Common Law Jurisdictions}

In municipal criminal laws of most common law jurisdictions, ${ }^{1}$ the for liability from criminal behaviour to arise, the constituents elements of actusreus must be ascertained. Tenets of contemporary criminal law tend to classify the action into acquired crimes and the resulting crimes. ${ }^{2}$ The above classification seems fascinating however their practical significance is more central to the latter discussion of how the concept of actusreus might differ in international criminal law. Primarily Clarkson and Keating who explore the notion actusreus from the context of private criminal law have outlined the core attributes associated with the actusreus concept. Namely there must be a criminal act either caused by the conduct of the accused or resulting as a subsequent consequence of the accused persons acts or actions. ${ }^{3}$ Imperatively Clarkson and Keating have also illustrated with theft and rape to demonstrate how the actusreus differs from one offence to another at least with regard to common law jurisdictions. ${ }^{4}$ Clarkson and Keating have also noted that the condemned criminal act ought to be voluntary. Quoting John Austin,

"Certain movements of our bodies follow invariably and immediately [with] our wish and [our] desires for [such] movements. Provided that the bodily organ [is said to] be sane, and the desired movement [is] not prevented by an outward obstacle $[\ldots]$ subsequent movement constitute the humans volitions." ${ }^{5}$

In the same ethos, Smith and Hogan on criminal law have assertively emphasised the underlying rule enshrined in the cited Latin maxim: actus non facitreum nisi mens sit rea. ${ }^{6}$ Literally imply that a person is not criminally liable for his conduct in absence of proof that his conduct can coincide with their state of mind by the time the offence was committed as

\footnotetext{
${ }^{1}$ Common law jurisdictions are majorly States that adopted principles of the English Common law. Many of these States in the present day tend to be members of the Common Wealth such Pakistan and India formerly constituting British India, Ghana formerly the Gold coast, Malaysia, Bangladesh, Singapore. Historically a vast majority of Common wealth States were former colonies of Great Britain.

${ }^{2}$ CMV Clarkson, H M KeAting AND SR Cumming, Clarkson AND KeAting CRiminal LAW 72 (7th Edition, Sweat and Maxwell).

${ }^{3}$ Re White [1910] 2 KB 124, see also CMV Clarkson, H M KeAting ANd SR Cumming, CLARKson AND KeATING CRiminal LAW 72 (7th Edition, Sweat and Maxwell).

${ }^{4}$ CMV Clarkson, H M KeAting and SR Cumming, Clarkson ANd KeAting CRiminal LaW 74 (7th Edition, Sweat and Maxwell).

${ }^{5}$ At 74.

${ }^{6}$ David Ormerod Smith and Hogan, Criminal Law 46 (Oxford University Press 2010).
} 
seen in Woolimington $v . D P P .^{7}$ There are a few exceptional cases in private criminal which with the above rule of criminal liability might not necessarily be followed such as; inchoate offences, offences of strict liability and statutory offences. In other wards the act alone or mensreus might suffice in some of the offences. As seen in tariff offence, offences of attempted murder, punishment could still be given without the coincidence of the act with the accused person's state of mind.

\section{B. 'ActusReus' under International Criminal Law}

The law regulating aspects of how mens rea is established by the ICC is understated under Article 30 of the ICC. ${ }^{8}$ In above law it has been noted that the persons is held liable for an offence under the jurisdiction of the court in cases where the material elements of the offence have been committed with knowledge and intent.In this case the concept of intent in relation to conduct has been defined to imply the party meant the conduct that led the offence.

Furthermore in relation to the consequences implies that the party meant their conduct to bring about or to cause the consequences. ${ }^{9}$ It must be noted that unlike private criminal laws that deal with cases of omissions to act, international criminal never made the express portions that will deal with cases where the party committees the offence as a result of their omission to act. ${ }^{10}$ In this respect it must understood that human rights takes a twofold approach considering that in some instances the treaties require that the states to respect the right which imply the must refrain from acting in certain ways.

\section{C. 'Mens Rea' in Private Criminal Law under Common Law}

The notion of mense rea' basically refers the cases where the personthat has committed the crime but has the guilty state of mind. This state mind of mind has in some cases been associated with the premeditation that can be evidence of the actor's malicious forethought. ${ }^{11}$ In cases of those

\footnotetext{
${ }^{7}$ Woolimington v. DPP 1935 AC 462.

${ }^{8}$ Rome Statute Article 30. See also Clare de Than and Edwin Shorts, Internationals Criminal Law and Human Right 4 (London 2003).

${ }^{9}$ CMV Clarkson, H M KeAting AND SR Cumming, Clarkson ANd KeAting CRiminal LAW 72 (7th Edition, Sweat and Maxwell).

${ }^{10}$ David Ormerod Smith and Hogan, Criminal Law 46 (Oxford University Press 2010).

${ }^{11}$ Richard. Buxton, Some Simple Thoughts on Intention, CRIMINAL LAW REVIEW 484-497 (1988), see also Lorraine Wilkinson, Murder and Manslaughter-A Single Offence of Homicide? 5(2) COVENTRY LAW JOURNAL 39—45 (2000).
} 
offences where the accused had the preconceived notion but the lacked the required mensereas this implies the person's will be accountable for attempted offences in the criminal law.

\section{Contrasting Civil Law Systems with the Common Law Criminal Law}

The present state of international criminal law is partly a product of the two major international systems in the world, namely; the common law and the civil law. The former is known to be adversarial while the latter is largely inquisitorial. In the same ethos the latter is asserted to be friendlier to the victim as opposed the latter. ${ }^{12}$ The argument that the civil systems is more victim friendly far from sounding convincing bearing in mind that the both systems have capacity the deliver the right to justice. In the same respect all systems could be equally misused by the parties. It seems as if the efficiency of criminal trial in both cases is very likely to depend on effectiveness of the main actors in the criminal justice system. It is less to do with the type of legal system and the extent to which it is friendly to the victim as propounded by Mikaela. ${ }^{13}$ By and large regardless of the shortcomings, the two type of criminal justice are used by domestic courts to deal with suspects at the national level. Under the auspices of those two legal traditions at least offences committed during armed conflict are dealt with apparently using the codified rules of procedure from those national models of the criminal justice systems.

\section{THE HiERARCHY STRUCTURES OF LEADERSHIP IN MILITARY LAWS AND INTERNATIONAL CRIMINAL LAW}

In this case it is imperative to understand that most of the armed groups have some orderly chain of command to qualify for combatant status. ${ }^{14}$ It is through a systemic chain of command through which attacks ought to be directed across from senior to the juniormembers of the armed forces. Accordingly most of the manuals and the codes of practice used by military tend to have some sort of a hierarchal structure in place. This hierarchical leadership within the military structure is partly vital for purposes of distinctiveness under the third Geneva Convention. Most this paper is more

\footnotetext{
${ }^{12}$ Mikeala HeKKila, International Criminal Tribunals and Victims of Crime Instituted of HumAn Rights 50 (Abo Akademi University, International Institute for Human Rights 2005). ${ }^{13} \mathrm{Ibid}$, at 51 .

${ }^{14}$ Geneva Convention Relative to the Treatment to Prisoners of War (adopted August 12, 1949, entered into force on October 21, 1950), 75 U.N.T.S. 135, 136 (hereafter GCIII); Article 4 A (2) paragraph (a).
} 
interested in using that hierarchical leadership for purposes of illustrating the role it might play in understanding as to why some of the crimes that subsequently breach the fundamental norms of humanity could be a result from its significances. Some of those include; the maximum obedience, utter submissiveness and utmost obedience to instructions of the superiors by their subordinates.

\section{CAUSATION OF THE HuMAN RightS ViOLATIONS}

The above concept of causation in international criminal law might appear largely inconsistent with the presumption that mankind is directly responsible for their actions. It is vividly possible that the actions that are committed during armed conflict by the juniors might in some of the cases be a result of junior acting in accordance in the utmost compliance with the instructions without an action being a direct consequence of the junior's personal volition. Claire and Edwin have noted that the issue of caution is yet another aspect that was raised to determine during the Rome conference but it left $\mathrm{t}$ was left case law. ${ }^{15}$ From the time their text was published ask lot of development have happened in the areas of international criminal law. The manner in which the issue of causation for war crimes has been viewed under international criminal is no longer attributed to the aspects of the western and issues criminal of law.

\section{INCHOATE AND CRIMES OF COLLECTIVE PARTICIPATION}

Considering all the crimes under the ICC Statute, such as; war crimes, crimes against humanity and grave breaches of the Geneva Convention, there is likelihood that the listed offences could result from instructions given by a third party and complied with by the junior. It be must highlighted that in such instances have certainly made the concept of inchoate offences fundamentally useful in the enforcement of international criminal law. ${ }^{16}$ The decision in Lubanga's pre-trial confirmation could be cited to exemplify such instances of the co-perpetuators conductor. ${ }^{17}$ In this case it is worthwhile emphasizing that third party perpetuators make the high likelihood of Article 23(3) of the ICC Statuteto become of fundamental

\footnotetext{
${ }^{15}$ Cliare de Than And Edwin Shorts, InTERnational Criminal Law ANd Human Rights 5 (London, Sweet and Maxwell 2003).

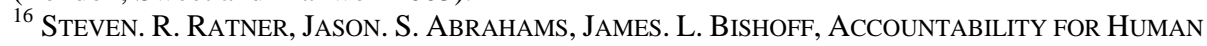
Rights Atrocities in INTERNATIONAL LAW: BEYOND the NUREMBERg LEGACy 143-144 (Oxford University Press 2009).

${ }^{17}$ Lubanga’s Pre-Trial Confirmation Decision paragraphs, at 342—367.
} 
importance at this stage. ${ }^{18}$ In as far the issues relating to aspects of conspiracy are concerned, in international criminal law the concept of conspiracy is seems fundamentally restricted to tendencies of conspiring to committee genocide. ${ }^{19}$ It must behighlighted that other offences that are codified under the Rome Statute were never subjected to the rules of conspiracy.

A related aspect is the issue of collective participation as yet another term that has been developed overtime by courts when referring toacts that might be a direct or indirect consequence of joint enterprises that are undertaken by two or more parties. In other respects joint enterprises imply those atrocities that are committedby the parties in a collective manner, the expression accomplices has also been used. ${ }^{20}$ In this it must be mentioned the co-perpetrator also must be taken also involved in the commission of the international crime for the party other party is being tried. ${ }^{21}$

\section{INTERNATIONAL CRIMINAL LAW AND ITS SUBJECTS CONTRASTED WITH HUMAN RIGHTS}

In must be understood that one of the developments that has blossomed with the emergency of international criminal law is the issue of individual liability that was never available under international law. ${ }^{22}$ In essence the issue of having only states as the primary subjects of international law has been challenged and subsequently changed through international laws. In this case it might worthwhile highlighting the enforcement of human rights have remained solely reliant on the states as the primary subjects of international law. This make the international enforcement of the state based human rights obligations had to enforce. Bearing in mind that breaches against human rights are devoid of specific elements that can be attributed to distinctive acts and behaviours of mankind. Conversely this means that in as much as the non-state actors such as rebel armed groups, private security companies, multinational corporations and many other corporations are have constantly breached the fundamental human rights, it remains equally true that these are neither subjects of international law nor linked to state

\footnotetext{
${ }^{18}$ Article 23(3) of the ICC Statute, see also Claire and Edwin, at 7.

${ }^{19}$ Antonio Cassese, International Criminal Law 196-198 (Oxford University Press 2003).

${ }^{20}$ Article 23(3) of the ICC Statute.

${ }^{21}$ Claire de Than and Edwin Shorts, International Criminal Law and Human Rights 5 (London, Sweet and Maxwell 2003).

${ }^{22}$ SteVen R. Ratner, Jason S. Abrams, JAmes L. Scoff, AcCountability For Human Right Atrocities in INTERNATIONAL LAW, BEYOND THE NuREMBERg LEgACy 141 (3rd Edition, Oxford University Press).
} 
capacity in any manner. This makes the application of human rights obligations to such non-state actors challenging amidst their increasing participation inarmedconflicts.

In summary: the Interactions between the power of military seniority and influence such authority might on individual autonomy to make choice on whether to committee awar crime or abstain from criminal conduct remain somehow challenging. The complexities are linked to the nature of the military hierarchal working patterns. In the times of peace there are clear safeguards that the parties endeavour to uphold. In times of the armed conflict the regiments might be expected to express loyalty in addition to exhibiting a reasonable level of swiftness. This might partly account for the several lives of non-combatants that might perish in the event of armed conflicts. Otherwise assuming international was deterrent then armed conflict death rates of civilians ought to have drastically dropped overtimes. Hierarchal structures posing challenges to the choices of the combatants as to how they must avoid complying with superior instructions that might result criminal behaviour under the ICC, while their oath of military allegiance to act with loyalty to the leadership.

\section{CONCLUSION}

There are some similarities between international criminal law and the two main systems of private criminal law. Perhaps the former is a hybrid product of the latter is certain aspects. The effect of line of command might have reasonably influence on decisions of those to whom the instructions are issued. Consequently there might be a high likelihood of some combatants having to act contrary to their state of mind. Particularly bearing in mind those cases where acts are undertaken in compliance with traditions of a combatant's loyalty to the oath of allegiance. That external influence is unlikely to be encountered in typical cases of murder. Lastly international criminal law might be the liberator to the limitations of the State based enforcement model under human rights instruments. This illuminates a ray of hope to the vulnerable beneficiaries intended for the protection rendered by human rights instruments. Take For example; the violations of humanrights for persons with disabilities during belligerent occupation, the contravention of children's rights among many other vulnerable groups. 